\title{
The market route to higher education in UAE: its rationales and implications
}

\author{
Dr. Ali Bhayani \\ University of Wollongong Dubai
}

\begin{abstract}
Externalities with regards to higher education have increasingly being debated across the world, with many countries shifting part of the higher education responsibility to the individuals on the premise that it generates private benefits. The transformation of higher education from elite to mass system and inability of the government to shoulder the ever increasing burden of higher education; is cited as one of the reasons for adopting the market route to higher education and treating students as consumers. This consumerist turn to higher education has raised concerns about quality, critical pedagogy and the perception amongst employers that graduates lack skills. The market of higher education in UAE is relatively free, and with the proliferation of higher education institutions consumers have fair choice in deciding whether to pursue their education at public, private or University Branch Campuses (IBC). Purpose of this study is to evaluate the market of higher education in UAE as there are now questions about the viability and quality of such institutions.

This exploratory study is intended to give insights about the effectiveness of market route in UAE by soliciting the employer's perceptions of different institutions and preparation of students for employment. The study revealed that the employers prefer graduates from public universities or IBC's as compared to private ones citing the concerns of quality of the graduates coming out of the private institutions. The policy implications for state and universities are discussed.
\end{abstract}

Key Words: UAE, Higher Education, Quality, Market Based Steering, Consumer Culture, Marketisation

Dr. Ali Bhayani

Assistant Professor of Marketing, University of Wollongong, Dubai, UAE

Email: alibhayani@uowdubai.ac.ae

Tel: +971566193001 


\section{Introduction}

Higher education in the Gulf has seen increased spending in recent years on the back of high oil prices. However, Gulf States are increasingly shifting part of the burden of higher education to private players in the wake of transformation of higher education from elite to mass system. Most of these Gulf States have adopted market route to expand the system by involving private players and giving consumers (students) choice in selecting the universities and colleges they want to study. Adoption of market route is not limited to UAE but has been increasingly being adopted in other Gulf countries. However, the biggest impact has been seen in UAE with the influx of the private universities and colleges in the last decade and now it is ranked second in terms of student numbers just behind Saudi Arabia. About $70 \%$ of the 120,000 students, in UAE, study in the private sector (without public funding); and most of them are expatriates. The process of shifting higher education burden to the private sector, relying on the market forces and giving choice to students is termed as marketisation. It has become a worldwide phenomenon making HEls compete in the free market for funding and students (Bok 2003; Dill and Sporn 1995; Slaughter and Leslie 1997; Sporn 1999), and this process is essentially irreversible (Brown 2005).

It is argued that market route can help in efficient allocation of resources while regulations can impede growth and development (Friedman 1962). The role of state has been transformed from management and control to that of oversight (Van Vught 1989) and has resorted to delegating the responsibility of higher education to the private players thereby adopting the policy of steering from distance. It relies on traditional demand and supply forces to allocate resources and ensure quality (Jongbloed 2003). Even public universities are asked to submit to market forces and compete in market-place for students and funding. Critics have argued that submitting to the neo-liberal market forces may impact on quality and be detrimental to long term employability of graduates (Barr 2004) and would also impact on research that benefits the society (Slaughter and Leslie 1997). It is, therefore, necessary to assess whether the market forces are able to bring in the efficiency and effectiveness that they were expected to bring. Teaching quality is crucial, in UAE as most of the universities are teaching oriented. Graduate preparedness for the world of employment, a quality indicator, has attracted attention due to the rising trend of unemployment or employed in so called 'non-graduate' jobs (Bourner et al. 2011). Up-to a fifth of the graduates are without jobs six months after graduating in United Kingdom (Paton 2012) and the situation is not different elsewhere. Many are questioning the increased role of market route to higher education and treatment of student as customer.

It is possible to blame economic system if there is unemployment in recessions. However, if the available graduates are unprepared for the world of employment then the relevance of the higher education has to be assessed. Universities are increasingly 
focusing on employability skills to overcome persistently high unemployment rate amongst new graduates (King 2009). It is also possible that the graduates from reputed institutions are able to find employment while the graduates from low ranking universities are struggling. The study is intended to look at the last dimension by assessing the preference of employers for graduates from particular universities (Little 2001). Therefore, the central research questions of the study would be:

1. What are the perceptions of the employers about the quality of the graduates recruited by them?

2. Whether there is preference given to graduates from public, private or foreign universities?

3. What is the effectiveness of the market route in meeting the labour market demands in UAE?

The next section offers a brief summary of the marketisation in the academic literature, its rationales and critical evaluation of treating students as customer.

\section{Higher Education as a 'Public Good'}

Higher education has traditionally been regarded as the 'Public Good', and its mission extends beyond research and teaching (Bok 1982). It includes providing education for democratic commitment, serving the society and communities, making knowledge available to the community, advancing knowledge through research, developing the intellectual talents of students, contributing to the community and economic development, and creating leaders for various sectors (Kezar et al. 2005). The higher education is a social contract and has the responsibility to meet societal needs i.e. externalities (Bok 2003; Slaughter and Rhoades 2004; Zemsky et al. 2005). It is argued that higher education plays a pivotal role in generating skilled people for the labour market which is critical for the nationalisation of workforce in UAE; and; therefore, it is necessary to understand whether the higher education institutions adequately prepare students for the labour market.

Traditionally, the State funded the higher education on the premise of externalities and 'public good'. However, it is argued that the benefits of higher education accrue to individuals and; therefore, they need to share part of the higher education cost as it might not be possible for a state to support ever increasing number of students entering higher education (Barr 2004; McPherson et al. 1993). Use of the market mechanism in higher education is not a new phenomenon, but, the one promulgated by Freidman in 1962 who brought education under the purview of market while acknowledging the fact that there exist externalities. Higher education systems with adequate funding directly to the 
institutions were found to be less responsive to the innovation than the ones with less than adequate funding (Friedman 1962).

Adoption of the market also implemented the new public management bringing efficiency and effectiveness to the higher education sector by asking universities to do more with fewer resources (Currie 1998; Teixeira et al. 2004) resulting into greater benefit to the society (Leslie and Johnson 1974). Market forces can make institutions reassess the decisions regarding costs, prices, course mix, personnel, process and product quality (Dill 1997a; Williams 1996). Market route is adopted with the belief that 'freeing, facilitating, and stimulating markets in higher education will provide academic institutions with incentives to improve the quality of teaching, and research, to enhance academic productivity, and to stimulate innovations in academic programs, research, and services to benefit the larger society' p.168 (Dill 1997a).

Apart from the efficiency and effectiveness, it is argued that market forces seeks to empower the students (customers) and bestow them with greater choice, flexibility and control of the education process by providing them with tools like performance indicators, league tables and student surveys. It is expected that these measures will put students in the driving seat and help apply pressure on universities to become marketing oriented. This consumer choice will play a role in making universities responsive to student's needs (Naidoo et al. 2011). So what are the components of marketisation?

Another rationale for using market forces was the inability of the state to meet the need of mass higher education through its limited resources especially in times of austerity measures. Both public and private universities were asked to shoulder the burden of higher education. It is argued that if the government goes all out to fund higher education it will be limited to one strata of the society and will undermine equitable access, harm efficiency and even quality (Barr 2004; Johnstone 1998; World-Bank 1994). It is suggested that the funding need to be available only to the lower strata of the society (McPherson et al. 1993) and eventually helps in transition of higher education from elite to mass systems (UNESCO 1995; World-Bank 1994).

French Social theorist Pierre Bourdieu has argued that higher education is expected to provide social mobility, but in reality the current state of higher education merely reinforces the power equations in society (Moore 2004). The reason cited by Bourdieu is that those who succeed at education are the cream of middle class as opposed to working class as they possess cultural and social capital. Private higher education might result in excluding marginalised sections of the society and widen the gap between rich and poor.

Free market model in higher education comprises of eight conditions (Jongbloed $\underline{2003}$ ). These eight conditions are relevant to regulations and control of private higher education. 
Figure 1 Eight conditions for a market

Four freedoms for providers

1. Freedom of entry

2. Freedom to specify the product

3. Freedom to use available resources

4. Freedom to determine prices
Four freedoms for consumers

1. Freedom to choose a provider

2. Freedom to choose a product

3. Adequate information on prices and quality

4. Direct and cost covering prices paid

However, use of market forces also involves relaxation of regulations with regards to public higher education and allows the universities the freedom regarding finances, personnel, and curriculum, essentially devolving control and steering it from distance (Huisman 1996; Volkwein 1987). Many a times devolvement of control is accompanied by reduced funding making it incumbent for pubic HEl's to generate revenue from private sources (Slaughter and Leslie 1997; Slaughter and Rhoades 2004) bringing about innovation, efficiency, increased productivity and greater effectiveness.

Overall, use of market forces is undertaken to improve access, promote efficiency, drive innovation and make higher education institutions more entrepreneurial.

\section{Has the market been able to deliver these noble goals?}

Massification of higher education had compelled the State to use the market in efficient allocation of resources. However, there are apprehensions that simply leaving higher education to the free market mechanism might not lead to socially optimal outcomes (Nickell 1996). One of the key requirements of the free market systems is the availability of the information to enable students to select the best institutions and shun the low quality ones. This information includes information about the programs, value addition, faculty qualifications and graduate employability data to make informed decisions (Dill 1995). However, many a times the information is either not readily available or students might not be use it making decisions choose a university. This might lead to distortion of the market where students, parents and employers rely on reputation of the university or heuristics rather than quality indicators. Universities, therefore, focus on achieving the status, prestige and reputation rather than trying to allocate resources efficiently (Breneman 1981). In the pursuit of excellence, universities often divert resources to research at the expense of teaching (Brewer et al. 2001; Dill and Soo 2004; Ehrenberg 2002).

It is argued that the free market system has not shown desirable results in other sectors of the economy as demonstrated by the financial crisis of 2008-9. Moreover, the markets have not been able to deliver socially responsible outputs, and there are concerns that it might not work in the future especially in the higher education sector (Kezar 2008). It is also argued that proper functioning of the market would require 
accountability systems, change in culture, regulatory control and above all provision of information on graduation rates, widening access, teaching infrastructure and graduate employability. Competitive environment created in the wake of consumerist turn can lead to arms race in admissions and increase in prices which might not be highly efficient and would require the regulator to step in and control the market forces (Bok 2003; Zemsky et al. 2005). The state can play the crucial role of the regulator as well as a provider of the necessary information to stakeholders about program quality, licensure, accreditation, graduation rates, employability etc.(Dill 1997a; Winston 1999) and can help reduce 'quality uncertainty' by distinguishing good and inferior quality products in the marketplace (Akerlof 1970).

Market also gets distorted due to the subsidies given to some providers. As far as higher education is concerned, it is either directly or indirectly subsidised by the state to ensure that it meets its qualitative and quantitative targets and, therefore, the consumers do not pay cost covering prices (Jongbloed 2003). In many instances, while public higher education gets substantial support from state, the private providers might not be able to recover the whole cost of higher education by charging market fees and might force them to cut corners (Brown 2005). These include shortage of teaching staff, less qualified staff to minimise cost, extra teaching loads on existing staff, ignoring plagiarisms, engaging services of others to produce coursework, crowded classrooms, teaching only examination areas, declaring questions in advance to produce outstanding results, cases of examination irregularities, inadequate resources for scientific training, inadequate library resources and lack of discipline amongst students (Brown 2000; Ouma 2008). Treating students like customers can have an adverse impact on pedagogical processes (Cheney et al. 1997) as they might want to take the easiest route disregarding the acquisition of higher order skills, dispositions and attitudes. Student satisfaction survey can also result into policies devised to palliate short term student's satisfaction leading to long term loss (Hart and Rush 2007). Universities are learning to balance the maintenance of high academic standards and customer satisfaction but can in no way grant students the 'sovereign consumer' status.

Use of market forces is not abominable rather it has driven institutions to use strategic management tools from the corporate world to understand the consumers, their preferences and position the products in mind of consumers. Marketing orientation in universities can make universities more flexible, resilient and responsive to the market and eventually it can result in higher quality programs. However, the state needs to provide a level playing field to both private and public universities in terms of steering and funding, encourage public universities to diversify the funding base and allow competition in the market as make universities innovative (Shattock 2009). 
The competition for funding and students as envisaged by the market can lead to quality uncertainty making it difficult for consumers to discern between good and bad providers in the market. Often the judgment about the university is based on the acceptability of credentials of the university in labour market. Employability skills amongst the graduates might not lead to higher employment rate. Rather, many a times it is dependent on the perception about university's image and rigour in mind of prospective employers (Bourner et al. 2011).

The student's preparedness for the labour market could be evaluated by assessing students experience survey. However, the opinions of students, though valuable, needs to be used with caution as higher education is a service where students are co-creators of the service (Naidoo et al. 2011) and need to put an equal amount efforts to receive service. Student's aptitude and attitude play an equally decisive role in facilitating the learning in higher education (Cooper 2007) and rigour through which they have gone through might impact on their ability to master skills in the workplace (Bourner et al. 2011). This leads us to question whether employers have a preference for graduates from any specific type of institutions. If employers have less trust in private universities, then there are questions about the quality of these institutions.

In conclusion, it can be said that the use of market forces can facilitate mass higher education and alleviate a part of the higher education burden from the state. It can bring in efficiency, effectiveness and can enhance the quality of the provision. However, this would need effective regulation and provision of information about quality to the stakeholders.

\section{Higher Education Landscape of UAE}

There is a total of 116 higher education institutions in UAE comprising of 3 federal universities, 78 institutions licenced by Ministry of Higher Education and Scientific Research (MOSHER) and 38 institutions licensed by other government bodies (CAA 2011; CAA 2012; KHDA 2012). There is a total of 37 International Branch Campuses (IBC) operating in UAE (Lawton and Katsomitros 2012).

UAE government maintains a liberal public higher education catering to national students, and at the same time allowing private players to cater to more than $70 \%$ of the 120,000 students. Public institutions are highly regulated, and liberal funding has resulted in less innovative and entrepreneurial approach on their part.

UAE has a federal regulatory body in the form of Ministry of Higher Education and Scientific Research (MOSHER), and each of the emirates has its own regulatory body as illustrated in figure 1. CAA (Commission of Academic Accreditation) is the arm of MOSHER to licence and accredit universities and colleges in UAE.

Figure 2: REGULATORY BODIES in UAE 


\begin{tabular}{|c|c|c|c|}
\hline \multicolumn{4}{|c|}{ Federal Level } \\
\hline \multicolumn{4}{|c|}{ Ministry of Higher Education and Scientific Research (MOSHER) } \\
\hline \multicolumn{4}{|c|}{ Emirate Level } \\
\hline Dubai & Abu Dhabi & Ras Al Khaimah & Sharjah \\
\hline $\begin{array}{l}\text { Knowledge and } \\
\text { Human } \\
\text { Development } \\
\text { Authority (KHDA) }\end{array}$ & $\begin{array}{l}\text { Abu Dhabi } \\
\text { Education Council } \\
\text { (ADEC) }\end{array}$ & $\begin{array}{l}\text { RAK Educational } \\
\text { Zone (REZ) }\end{array}$ & $\begin{array}{l}\text { Sharjah Educational } \\
\text { Zone (SEZ) }\end{array}$ \\
\hline
\end{tabular}

Freedom of entry is regulated by MOSHER outside the free zones. However, inside the free zones it is relatively easy. Abu Dhabi and Dubai have stringent measures while other emirates are lenient in setting licensure criteria. While federal universities have the freedom to offer programs, private institutions are subjected to accreditation of programs to ensure quality. IBC's in free zones are outside the purview of CAA and can only offer programs offered at the home campus. Overall, HEl's have the freedom to specify the programs in UAE. Private universities and colleges have zero funding support from the state but have the freedom to raise and use resources, choose students and recruit lecturers. On the other hand, public HEl's cannot accept self-paying students or expatriates have limited freedom to make staff, and faculty appointments, have limited freedom to pursue income generation activities, fund raising, contract training and research. This can have an impact on effectiveness and efficiency of HEI (Dill 1997b). Public universities cannot charge market based prices while private universities need approval from state before deciding the prices limiting the freedom to charge prices. Market can get distorted due to government subsidies (Brown 2005) available to public HEl.

Students in UAE opting for Private HEl have the freedom to choose the product making them discriminating educational consumers. On the other hand, public HEls have limited number of seats leading to constraints in choosing the specialisation. The students who are not able to secure the specialisation of their choice might turn to private HEls. However, the inadequacy of information about the quality of programs, graduation rates and graduate employability has had an impact on marketisation in UAE. Information like rankings, quality assessment reports, evaluation reports and league tables help parents and students in making an informed decision, but too much information might lead to consumer confusion (Turnbull 2000). Many a times students might not use the above quality indicators but are swayed by heuristics like university's prestige (Moogan et al. 1999), high admission scores as an indicator of quality (James et al. 1999) and accreditations like AMBA, AACSB etc.(Naidoo et al. 2011) or rely on word of mouth.

Based on the above, it is now possible to redraw the figure 1 to reflect UAE's marketisation. 
Figure 3: Eight conditions for a market

\begin{tabular}{|l|c|l|c|}
\hline \multicolumn{1}{|c|}{ Four freedoms for providers } & Rank & \multicolumn{1}{|c|}{ Four freedoms for consumers } & Rank \\
1. Freedom of entry & 1 & 1. Freedom to choose a provider & 1 \\
2. Freedom to specify the product & 2 & 2. Freedom to choose a product & 2 \\
3. Freedom to use available resources & 2 & 3. Adequate information on prices and quality & 5 \\
4. Freedom to determine prices & 2 & 4. Direct and cost covering prices paid & 3 \\
\hline 1= Free Market 2=Relatively Free Market 3= Partially Free Market 4=Relatively Restricted $5=$ \\
Restricted
\end{tabular}

In conclusion, it can be said that the UAE higher education market is relatively free or both providers and consumers. State can improve the free market mechanism by providing adequate information on quality indicators like graduation rates and employability.

\section{Research Objectives and Methodology}

Critics of the use of market forces and giving consumerist turn to higher education have affected the quality of higher education in UAE. Often, we hear noises that the private higher education institutions are highly commercialised and are cutting corners in order to generate profits. Students and potential students are concerned about the graduate unemployment (Glover et al. 2002) and there are questions whether there is oversupply of graduates or graduates lacking employability skills or only graduates from some universities are able to find employment due to preference of employers about the perception of different universities. The study will, therefore, focus on taking views of employers (Silverman 2006) about their preference of graduates from different types of higher education intuitions.

The research essentially is interpretivist in nature. However, there are small aspects of 'nested' traditional positivist style of model verification (Hesse-Biber and Leavy 2006) as the study has used some statistical techniques to quantify the data collected from qualitative analysis. Some researchers have proposed making some use of quantitative techniques like (Maxwell 1992) who has clarified that: "This is not to argue that issues of sampling, representativeness, and generalizability are unimportant in qualitative research" (P. 293).

A sample of employers in UAE was selected from across the leading sectors contributing to the national economy. A telephonic interview with select respondents was conducted to assess the reasons for their preference. It was felt that the telephonic interview provided an opportunity to probe and seek clarifications rather than a structured survey. In total, there were 34 respondents from 23 organisations. Most of the respondents are primarily involved in recruiting national graduates. Therefore, the perceptions about recruitment are tilted more towards recruitment of national Emirati graduates. 
This study is an exploratory study undertaken to assess the use of market in UAE with limited sample size due to the constraints on time and resources. Though, the sample size is small, it is representative of the most important sectors of the economy. The study provides a stepping stone to further studies on the topic, with a large representative samples, to establish correlation and generalise the results.

\section{Research Findings}

On an average, the corporates recruited 10-25 graduates per annum. While bigger corporates even recruited more than $\mathbf{4 0}$ graduates, smaller organisations recruited lesser numbers. About half of the respondents were satisfied with the quality of graduates recruited in last 3-5 years. However, one third of the respondents were dissatisfied while about one fifth were highly dissatisfied with the quality of graduates coming out of universities and colleges. Respondents felt that education in universities and colleges is not aligned to the requirement of the industry. One of the human resources manager commented:

"The graduates need a lot of training before they can start work and also do not possess transferable skills that are needed across all sectors"

While the link between employability skills and graduate employment is weak (Bourner et al. 2011), there is some role played by perception about the university's image. For example, in UK employers still prefer graduates from traditional high profile universities than ones graduating from new universities with a focus on employability skills (Harvey et al. 2002). It is, therefore, important to know the preference of employers for any specific type of institution. In the current study, when it was asked to specify their perceptions about graduates coming out from different types of institutions, about two third of the respondents were satisfied with the quality of graduates coming out of public universities (that included federal institutions, American University of Sharjah and other public institutions). Public universities scored 2.65 on the scale of 4 . On the other hand, local private institutions were perceived to be providing lower quality with $76 \%$ of the respondents giving thumbs down to graduates coming from these universities. The branch campuses fared quite well and were regarded as providing higher quality graduates with more than three fourth (83\%) of the respondents preferring the graduates of the IBC's. One of the respondents explained the preference thus:

"The grades required to get admissions in public universities is quite high and; therefore, these universities have better output, as well. Students who go to private universities are the ones not able to secure admissions in public universities due to their grades. Difference is obvious."

One of the respondents explaining the preference for graduates from IBC stated:

"I have generally found the IBC graduates with better knowledge and positive attitude as compared to others recruited by me". 
However, the limelight was taken by the graduates educated abroad. About $94 \%$ of the respondents felt that these graduates have better skills, competencies, attitude, behaviour etc. There was almost a unanimous view that the graduates coming from reputed universities are of higher quality than local graduates. This can be seen in the backdrop of preference of employers to recruit graduates from reputed universities (95\%). One of the respondents explained the reason of preferring graduates from abroad:

"Students coming from abroad have a positive attitude towards work and have lived and studied in a multi-cultural society and have excellent skills to adjust and learn"

Another respondent explained his preference thus:

"It is not a matter of knowledge, skills and competencies; it is the intellectual development that is a critical aspect and we found graduates trained abroad being able to demonstrate better level of critical thinking than local graduates".

When the respondents were asked as to what played a role in shortlisting candidates for an interview, they indicated that 'Qualifications from reputed university' did play a role. This indicates that employability skills might not lead to a graduate getting a job, but the perception that a graduate has come from a reputed place does play a role. Federal and foreign universities tag would influence the decision of the employer. Many private universities and colleges, by focusing on narrow goals, inflate the grades in order to satisfy student-consumers thereby diluting their standards (Sonner 2000). This would have influenced the perception of the employers about a particular type of institution.

The perception of employers and their preferences are one indication to judge whether universities are able to produce graduates as demanded by industry. Many a times, employers need graduates who are trainable with work place discipline and commitment to work. Some of the employers indicated that graduates coming from reputed institution have higher work ethics as they have undergone demanding assessments and examinations. On the other hand, grade inflation, hiring of adjuncts, easy assessments can help generate economic profit but would lead to dilution of image in minds of employers and can affect graduate employability in the long run.

\section{Policy Implications for UAE}

Involvement of the market has become an integral part of the higher education systems in most countries due to the massification of higher education and funding constraints of the State. However, the state and HEl's can act responsibly to avoid excessive commercialisation of the sector. The growth of higher education sector in UAE is a positive sign and has played a critical role in providing the employers with bigger pool of the talented graduates. There are some institutions that have a better reputation, and this influences employer's perception. As can be seen from this exploratory research, the graduates from public universities are preferred over those graduating from private 
universities while graduates from IBC's are preferred over both. The state needs to play a role in ensuring that the higher education sector is regulated, and there is a real market based steering in UAE and some policy implications are mentioned here:

a) Creation of a level playing field between public and private universities to discourage private universities from cutting corners. One of the ways to create a level playing field use vouchers (Jongbloed and Koelman 2000) for the national students instead of asking them to choose only public universities. Students will be empowered, and the ones responsive to student's needs, provide better quality teaching infrastructure, and have higher graduate employability can flourish. However, for the vouchers to be effective the state needs to prevent distortion of the markets and provide information about the quality indicators.

b) Level playing field also means that the accreditation system needs to be strengthened though CAA (Commission of Academic Accreditation) and all universities and colleges, whether in free zones or outside the free zones, should have uniform regulatory standards.

c) A National Student Survey (NSS) administered by MOSHER can be instituted in order to provide information about the HEl's to the stakeholders and facilitate informed decision making. Though, the NSS might not be a sufficient indicator of quality, but it will to some extent help in applying pressure on the universities to be responsive, inclusive and effective. Lack of information is currently distorting the market in UAE.

d) On similar lines of NSS, MOHESR can work towards collecting data about graduate employability, salaries and jobs to give a fair indication about the quality of final output and their demand in the market.

e) Public HEl's can be given autonomy, in line with new public management, so that they can compete in the market of higher education and State can steer from a distance.

From the above discussions, we can conclude that the use of the market is here to stay as State alone cannot shoulder the burden of mass higher education system. The UAE higher education market is fairly liberal and student's choice has made it quite competitive. However, the market needs regulations so that private players are not allowed to offer substandard programs. Use of the market was highly successful in providing access to higher education but regulation, level playing field and provision of information would prevent distortion of the market. 


\section{References}

Akerlof, G. A. (1970). "The market for "lemons”: Quality uncertainty and market mechanism." Quarterly Journal of Economics 84(3), 488-500.

Barr, N. (2004). "Higher Education Funding." Oxford Review of Economic Policy, 20(2), 264-283.

Bok, D. (1982). Beyond the ivory tower, Cambridge, MA: Harvard University Press.

Bok, D. (2003). Universities in the Marketplace: The Commercialization of Higher Education., Princeton: Princeton University Press.

Bourner, T., Greener, S., and Rospigliosi, A. (2011). "Graduate employability and the propensity to learn in employment: a new vocationalism." Higher Education Review, 43(3), 5-30.

Breneman, D. W. (1981). "Strategies for the 1980’s", in J. R. Mingle, (ed.), Challenges of Retrenchment. San Francisco: Jossey-Bass Publishers.

Brewer, D., Gates, S., and Goldman, C. (2001). In Pursuit of Prestige: Strategy and Competition in US Higher Education, Somerset, NJ: Transaction Publishers.

Brown, R. B. (2000). "Accountability in Higher Education: Have we reached end of the road? The case for a higher education audit commission"Professional Lecture. City: University of Surrey Roehampton.

Brown, R. B. (2005). "Higher Education and The Market: Protecting Quality and Diversity in a Market Driven System"Higher Education Policy Institute Seminar. City: UK.

CAA. (2011). Annual Report 2011. Commission of Academic Accreditation, Abu Dhabi,UAE.

CAA. (2012). "List of the Licensed Institutions in UAE. Commission of Academic Accreditation". City: Commission of Academic Accreditation: Abu Dhabi, UAE.

Cheney, G., McMillan, J., and Schwartzman, R. (1997). "Should we buy the 'student-as consumer' metaphor?" The Montana Professor, 7(3), 8-11.

Cooper, P. (2007). "Knowing your 'Lemons': Quality Uncertanity in UK Higher Education." Quality in Higher Education, 13(1), 19-29.

Currie, J. (1998). "Globalization practices and professoriate in Anglo-Pacific and North American universities." Comparative Education Review, 42(1), 15-29.

Dill, D. D. (1995). "Through Deming's eyes: a cross-national analysis of quality assurance policies in higher education." Quality in Higher Education 1(2), 95-110.

Dill, D. D. (1997a). "Higher Education markets and public policy." Higher Education Policy, 10(3-4), 167-185.

Dill, D. D., and Soo, M. (2004). "Transparency and quality in higher education markets", in P. Teixeira, D. Dill, B. Jongbloed, and A. Amaral, (eds.), Markets in Higher Education: Rhetoric or Reality? Dordrecht: Kluwer Academic Publishers.

Dill, D. D., and Sporn, B. (1995). Emerging Patterns of Social Demand and University Reform: Through a Glass Darkly, Oxford: Pergamon.

Dill, D. D. a. (1997b). "Accreditation, assessment, anarchy?: the evolution of academic quality assurance policies in the United States", in J. Berman, P. De Vries, and R. Williams, (eds.), Standards and Quality in Higher Education. London: Kingsley.

Ehrenberg, R. (2002). Tuition Rising: Why Colleges Cost So Much, Cambridge: Harward University Press.

Friedman, M. (1962). Capitalism and Freedom, Chicago: The University of Chicago Press.

Glover, D., Law, S., and Youngman, A. (2002). "Graduates and Employability:student perceptions of the personal outcomes of university education." Research into Post Compulsory Education, 7(3), 293-306. 
Hart, M., and Rush, D. (2007). "E-Learning and the development of 'voice' in business studies education." International Journal of Educational Management, 21(1), 68-77.

Harvey, L., Locke, W., and Morey, A. (2002). Enhancing Employability, Recognising Diversity: Making Links between Higher Education and the World Of Work. Universities UK, London.

Hesse-Biber, S. N., and Leavy, P. (2006). The Practice of Qualitative Research, Thousand Oaks CA: Sage Publications.

Huisman, J. (1996). "Diversity in the Netherlands", in V. L. Meek, L. Goedegebuure, O. Kivinen, and R. Rinne, (eds.), Mockers and the Mocked: Comparative Perspectives on Differentiation, Convergence and Diversity in Higher Education. Oxford: Pergamon Press.

James, R., Baldwin, G., and McInnis, C. (1999). Which university? The factors influencing the choices of prospective undergraduates. Higher Education Division, DEST, Canberra.

Johnstone, D. B. (1998). The financing and management of higher education: A status report on worldwide reforms, Washington: World Bank.

Jongbloed, B. (2003). "Marketisation in Higher Education, Clarks triangle and the essential ingredients of markets." Higher Education Quarterly, 52(2), 110-135.

Jongbloed, B., and Koelman, J. (2000). Vouchers in Higher Education? , CHEPS, Netherlands.

Kezar, A. (2008). "Is There a Way Out?: Examining the Commercialization of Higher Education " The Journal of Higher Education 79(4), 473-482.

Kezar, A., Chambers, T., and Burkhardt, J. (2005). Higher education for the public good., San Francisco: Jossey-Bass.

KHDA. (2012). Higher Education in Dubai. Knowledge and Human Development Authority, Dubai.

King, C. (2009). "Employability: exploring policy, provision and the implications of embedding employability within the higher education curriculum." Widening Participation and Lifelong Learning, 11(2), 32-41.

Lawton, W., and Katsomitros, A. (2012). International Branch Campuses Data and Developments., The Observatory on Borderless Higher Education.

Leslie, L. L., and Johnson, G. P. (1974). "The Market Model and Higher Education." Journal of Higher Education 45(1), 1-20.

Little, B. (2001). "Reading Between the Lines of Graduate Employment." Quality in Higher Education, 7(2), 121-129.

Maxwell, J. A. (1992). "Understanding and validity in qualitative research." Harvard Educational Review, 62(3), 279-300.

McPherson, M. S., Schaprio, M. O., and Winston, G. C. (1993). Paying the Piper: Productivity, Incentives, and Financing in US Higher Education, Michigan: University of Michigan Press.

Moogan, Y. J., Baron, S., and Harris, K. (1999). "Decision-Making Behaviour of Potential Higher Education Students. ." Higher Education Quarterly, 53(3), 211-228.

Moore, R. (2004). "Cultural capital: objective probability and the cultural arbitrary." British Journal of Sociology of Education, 25(4), 445-456.

Naidoo, R., Avi, S., and Ekant, V. (2011). "The consumerist turn in higher education: Policy aspirations and outcomes." Journal of Marketing Management, 27(11-12), 1142-1162.

Nickell, S. (1996). "Competition and Corporate Performance." The Journal of Political Economy, 104(4), 724-746. 
Ouma, G. W. (2008). "Higher education marketisation and its discontents." Higher Education, 56(2), 457-471.

Paton, G. (2012). "Up to a fifth of graduates 'without work' after university"The Telegraph. City.

Shattock, M. (2009). Entrepreneurialism in universities and the knowledge economy : diversification and organizational change in European higher education, Maidenhead: Open University Press.

Silverman, D. (2006). Interpreting qualitative data : methods for analysing talk, text and interaction, London: SAGE.

Slaughter, S., and Leslie, L. L. (1997). Academic capitalism : politics, policies, and the entrepreneurial university, Baltimore, Md. ; London: Johns Hopkins University Press.

Slaughter, S., and Rhoades, G. (2004). Academic capitalism and the new economy : markets, state, and higher education, Baltimore: Johns Hopkins University Press, 2010.

Sonner, B. (2000). "A Is for 'Adjunct': Examining Grade Inflation in Higher Education." Journal of Education for Business, 76(1), 5-14.

Sporn, B. (1999). "Towards more adaptive universities: Trends of institutional reform in Europe." Higher Education in Europe, 24(1), 23-33.

Teixeira, P., Dill, D., Jongbloed, B., and Amaral, A. (2004). "Markets in Higher Education: Rhetoric or Reality?". City: Kluwer Academic Publishers: Dordrecht, London.

Turnbull, P. W. (2000). "Customer Confusion: The Mobile Phone Market." Journal of Marketing Management 16(1-3), 143-163.

UNESCO. (1995). Policy Paper for Change and Development in Higher Education. UNESCO, Paris.

Van Vught, F. A. (1989). Governmental strategies and innovation in higher education. Jessica Kingsley Publishers, London.

Volkwein, J. F. (1987). "State Regulation and Campus Autonomy", in J. C. Smart, (ed.), Higher Education: Handbook of Theory and Research. New York: Agathon, pp. 120-154.

Williams, G. (1996). "The many faces of Privatization." Higher Education Management and Policy, 8(1), 39-56.

Winston, G. C. (1999). "Subsidies, hierarchy and Peers: The awkward economics of Higher Education." Journal of Economic Perspectives, 13(1), 13-36.

World-Bank. (1994). Higher Education: The Lessons of Experience. World Bank, Washington, D.C.

Zemsky, R., Wegner, G., and Massy, W. (2005). Remaking the American University: Market Smart and Mission Centered, Piscataway, NJ: Rutgers University Press. 